\title{
The role of humic acid in stabilizing fullerene $\left(C_{60}\right)$ suspensions
}

\author{
Lu-qing ZHANG ${ }^{1}$, Yu-kun ZHANG ${ }^{1}$, Xiu-chun LIN $^{1,3}$, Kun YANG ${ }^{1,2}$, Dao-hui LIN $\$ 1,2$ \\ $\left({ }^{1}\right.$ Department of Environmental Science, Zhejiang University, Hangzhou 310058, China) \\ ('Zhejiang Provincial Key Laboratory of Organic Pollution Process and Control, Hangzhou 310058, China) \\ $\left({ }^{3}\right.$ College of Environmental and Biological Engineering, Putian University, Putian 351100, China) \\ †E-mail: lindaohui@zju.edu.cn
}

Received Apr. 30, 2014; Revision accepted June 13, 2014; Crosschecked July 20, 2014

\begin{abstract}
Natural organic matter (NOM) has a profound effect on the colloidal stability of discharged $\mathrm{C}_{60}$ nanoparticles in the water environment, which influences the environmental behaviors and risks of $\mathrm{C}_{60}$ and therefore merits more specific studies. This study investigates the effects of humic acid (HA), as a model NOM, on the aqueous stabilization of $\mathrm{C}_{60}$ powder and the colloidal stability of a previously suspended $\mathrm{C}_{60}$ suspension $\left(\mathrm{aqu} / \mathrm{nC}_{60}\right)$ with variations of $\mathrm{pH}$ values and ionic strengths. Our results reveal that $\mathrm{HA}$ could disperse $\mathrm{C}_{60}$ powder in water to some degree, but was unable to stably suspend them. The aqu/nC 60 could remain stable at $\mathrm{pH}>4$ but was destabilized at lower $\mathrm{pH}$ values. However, the colloidal stability of $\mathrm{aqu} / \mathrm{nC}_{60}$ in the presence of $\mathrm{HA}$ was insensitive to $\mathrm{pH} 3-11$, owing to the adsorption of $\mathrm{HA}$ onto $\mathrm{nC}_{60}$ and the increased electrosteric repulsions among $\mathrm{nC}_{60}$ aggregates. The colloidal stability of $\mathrm{aqu} / \mathrm{nC}_{60}$, with and without $\mathrm{HA}$, decreased as we increased the valence and concentration of the added cations. HA was found to mitigate the destabilization effect of $\mathrm{Na}^{+}$on the colloidal stability of aqu/nC 60 by increasing the critical coagulation concentration (CCC) of $\mathrm{Na}^{+}$, while $\mathrm{HA}$ lowered the $\mathrm{CCCs}$ of $\mathrm{Ca}^{2+}$ and $\mathrm{La}^{3+}$ probably by the bridging effect of $\mathrm{nC}_{60}$ with HA aggregates formed through the intermolecular bridging of the HA macromolecules via cation complexation at high concentrations of cations with high valences.
\end{abstract}

Key words: Fullerene, Humic acid, Colloidal stability, Natural organic matter, Nanomaterial doi:10.1631/jzus.A1400115 Document code: A CLC number: X52

\section{Introduction}

Fullerene $\mathrm{C}_{60}$ nanoparticles have triggered much attention by their unique physicochemical, electrical, and mechanical properties, which enable their numerous potential applications in electronics (Zhang et al., 2013), biomedicine (Colvin, 2003; Nakamura and Isobe, 2003), cosmetics (Takada et al., 2006), etc. $\mathrm{C}_{60}$ is inevitably released into the aquatic environment

\footnotetext{
${ }^{\ddagger}$ Corresponding author

* Project supported by the National Natural Science Foundation of China (No. 21337004), the National Basic Research Program (973) of China (No. 2014CB441104), the Zhejiang Provincial Natural Science Foundation of China (No. LR12B07001), the Specialized Research Fund for the Doctoral Program of Higher Education (SRFDP) (No. 20130101110132), the Fujian Provincial Natural Science Foundation of China (No. 2014J01053), and the Fundamental Research Funds for the Central Universities (No. 2014FZA6009), China CC Zhejiang University and Springer-Verlag Berlin Heidelberg 2014
}

with its widespread production and usage (van Wezel et al., 2011), and may thus threaten aquatic organisms and human health as well through food chains ( $\mathrm{Nel}$ et al., 2006; Oberdörster et al., 2006; Britto et al., 2012).

Once released into the water environment, the hydrophobic $\mathrm{C}_{60}$ will be presented as aggregates $\left(\mathrm{nC}_{60}\right)$. Ubiquitous natural organic matter (NOM), such as humic acid (HA), is likely to interact with the discharged $\mathrm{nC}_{60}$ and influence the aggregation/ dispersion behavior and ecotoxicity of $\mathrm{nC}_{60}$ (Bhatt and Tripathi, 2011; Kim et al., 2012). Therefore, it is essential to take into account the interactions between $\mathrm{NOM}$ and $\mathrm{nC}_{60}$ when elucidating the behavior of $\mathrm{nC}_{60}$ in natural water bodies.

Several studies have investigated the interaction between $\mathrm{NOM}$ and $\mathrm{nC}_{60}$ and the effect of $\mathrm{NOM}$ on the aggregation/dispersion behavior of $\mathrm{nC}_{60}$. Xie et al. (2008) observed significant changes in the aggregate 
size and morphology of $\mathrm{nC}_{60}$ with the addition of NOM. Li et al. (2009) revealed that NOM could effectively stabilize $\mathrm{nC}_{60}$ in the aqueous phase and $\mathrm{nC}_{60}$ nanoparticles may have been chemically modified under illumination. Mashayekhi et al. (2012) attributed the increased stability of $\mathrm{nC}_{60}$ to the transformation of surface properties through the HA adsorption. The adsorption of HA can increase electrostatic and steric repulsions among $\mathrm{nC}_{60}$ aggregates, and thus facilitate dispersion and stabilization of $\mathrm{nC}_{60}$ in water (Chen and Elimelech, 2007; Mashayekhi et al., 2012; Zhang et al., 2013). Moreover, environmental conditions (e.g., water quality parameters) may have profound effects on the interaction between $\mathrm{HA}$ and $\mathrm{nC}_{60}$ (Isaacson and Bouchard, 2010; Qu et al., 2010; Yang et al., 2013), which has not been well examined. Chen and Elimelech (2007) found that HA could increase the $\mathrm{C}_{60}$ nanoparticle stability in $\mathrm{NaCl}$ or $\mathrm{MgCl}_{2}$ electrolytes, but HA enhanced the aggregation at high concentrations of $\mathrm{CaCl}_{2}$. Therefore, water quality parameters, such as ionic strength and $\mathrm{pH}$, are likely to have significant effects on the colloidal stability of $\mathrm{C}_{60}$ in the presence of $\mathrm{HA}$, which merit further investigations.

This work is aimed to study the capabilities of $\mathrm{HA}$ in dispersing and stabilizing $\mathrm{C}_{60}$ powder in water and in maintaining the colloidal stability of $\mathrm{nC}_{60}$ suspension $\left(\mathrm{aqu} / \mathrm{nC}_{60}\right)$ as affected by variations of $\mathrm{pH}$ and ionic strength. The changes of zeta potentials and hydrodynamic sizes of the $\mathrm{C}_{60}$ powder and $\mathrm{aqu} / \mathrm{nC}_{60}$ under different $\mathrm{pH}$ values and the impact of ionic strength on the aggregation kinetics of the aqu/ $\mathrm{nC}_{60}$ in the absence and presence of HA were specifically examined.

\section{Materials and methods}

\subsection{Preparation and characterization of HA}

HA was purchased from Sigma-Aldrich. HA was purified before use and was characterized following the procedures detailed in Lin et al. (2012a; $2012 \mathrm{~b}$ ). HA of $500 \mathrm{mg}$ was dissolved in $10 \mathrm{ml}$ $1 \mathrm{~mol} / \mathrm{L} \mathrm{NaOH}$ solution, and adjusted to $\mathrm{pH} 7.0$ using $1 \mathrm{~mol} / \mathrm{L} \mathrm{HCl}$. The supernatant was obtained by centrifugation at $3000 \mathrm{r} / \mathrm{min}$ for $15 \mathrm{~min}$, and then was diluted to $1 \mathrm{~L}$ using ultra-pure water and used as the stock HA solution $(500 \mathrm{mg} / \mathrm{L}) . \mathrm{NaN}_{3}(200 \mathrm{mg} / \mathrm{L})$ was added to prevent HA from microbial interference. The HA solution was scanned with an ultraviolet (UV) spectrophotometer (SHIMADZU, UV-2450, Japan).

\subsection{Preparation and characterization of $\mathbf{a q u} / \mathbf{n C}_{60}$}

$\mathrm{C}_{60}$ powder was purchased from Nanjing XFNANO Materials Tech Co., Ltd., China. The elemental contents were measured using an elemental analyzer (Vario ELIII, Germany). Aqueous suspension of $\mathrm{C}_{60}$ was prepared following a solvent exchange procedure modified from previous works (Deguchi et al., 2001; Chen and Elimelech, 2006; Kim et al., 2010). $\mathrm{C}_{60}$ powder $(120 \mathrm{mg}$ ) was dispersed in $60 \mathrm{ml}$ of high-performance liquid chromatography (HPLC)-grade toluene by stirring for several hours, forming a clear dark purple mixture. The mixture was then added into ultra-pure water at a volume ratio of $1: 15$, resulting in two distinct phases. The resultant mixture was sonicated with a sonifier cell disrupter (KBS-150, Kunshan, China) for more than $4 \mathrm{~h}$, allowing for the evaporation of toluene. The stabilized $\mathrm{C}_{60}$ suspension $\left(\mathrm{aqu} / \mathrm{nC}_{60}\right)$ was obtained by centrifugation at $2000 \mathrm{r} / \mathrm{min}$ for $15 \mathrm{~min}$, and then stored at room temperature in the dark. The morphology and aggregate size of the aqu $/ \mathrm{nC}_{60}$ were examined with a transmission electron microscope (TEM; JEM-1230, JEOL, Japan). The hydrodynamic size and zeta potential were determined using a Zetasizer (Nano ZS90, Malvern Instruments, UK) at $25^{\circ} \mathrm{C}$ (Tian et al., 2010). The $a q u / C_{60}$ suspension was also scanned using the UV spectrophotometer.

\subsection{Suspension experiment}

A suspension experiment was performed to study the effect of HA on the aqueous stabilization of $\mathrm{C}_{60}$ powder. $\mathrm{C}_{60}$ powder $(10 \mathrm{mg})$ was added into $20 \mathrm{ml}$ of HA solutions ( $\mathrm{pH} 7.0,10 \mathrm{mg} / \mathrm{L}$ of $\mathrm{NaCl}$ ) with initial HA concentrations of $0,5,10,20$, and $40 \mathrm{mg} / \mathrm{L}$. The mixtures were sonicated $(240 \mathrm{~W}$, $40 \mathrm{KHz}$ ) for $1 \mathrm{~h}$ and were subsequently kept in a thermostat shaker $\left(150 \mathrm{r} / \mathrm{min}, 25^{\circ} \mathrm{C}\right)$ for $1 \mathrm{~d}$. The zeta potential and hydrodynamic size of the samples were measured right after the shaking process with the Zetasizer at $25{ }^{\circ} \mathrm{C}$. Each concentration was run in triplicate. The absorbance at $800 \mathrm{~nm}$ (UV800) was considered to be capable of quantifying the stabilized multi-walled carbon nanotubes (MWCNTs) (Lin et al., 2010; 2012a). Similarly, UV800 of the $\mathrm{C}_{60}$ 
suspension was in a positive correlation with the concentration of suspended $\mathrm{C}_{60}$ determined by a total organic carbon (TOC) analyzer (SHIMADZU, TOCVCPH, Japan), and the HA solution had no absorbance at $800 \mathrm{~nm}$ (Fig. 1). Therefore, the UV800 of the supernatant of the $\mathrm{C}_{60}$-HA suspension after settling for $0-2 \mathrm{~d}$ was used to measure the stability of the $\mathrm{nC}_{60}$ suspensions in the presence of different concentrations of HA.

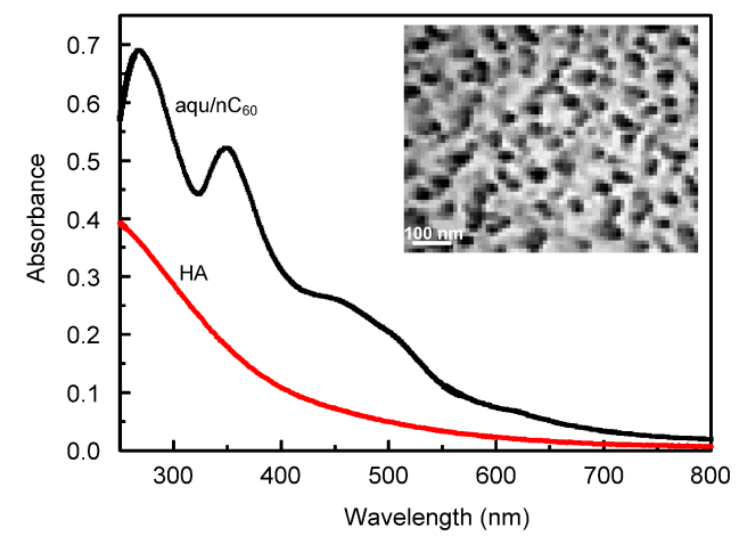

Fig. 1 TEM image of the aqu/nC 60 and $\mathrm{UV}$-vis absorbance spectra of the $\mathrm{aqu} / \mathrm{nC}_{60}(8 \mathrm{mg} / \mathrm{L})$ and $\mathrm{HA}(10 \mathrm{mg} / \mathrm{L})$

\subsection{Effect of $\mathrm{pH}$ on stability of $\mathrm{aqu} / \mathrm{nC}_{60}$ with and without HA}

The stock suspension of $\mathrm{aqu} / \mathrm{nC}_{60}(10 \mathrm{ml})$ was added into $22-\mathrm{ml}$ glass vials containing $10 \mathrm{ml}$ of ultrapure water or $20 \mathrm{mg} / \mathrm{L} \mathrm{HA}$ with $20 \mathrm{mg} / \mathrm{L} \mathrm{NaCl}$. The $\mathrm{pH}$ values of the suspensions were then adjusted to $3.0-11.0$ with several drops of $1 \mathrm{~mol} / \mathrm{L} \mathrm{NaOH}$ or $\mathrm{HCl}$ solutions. The mixtures were equilibrated (150 r/min) for $1 \mathrm{~d}$, and then their zeta potentials, hydrodynamic sizes, and final $\mathrm{pH}$ values were measured. Each $\mathrm{pH}$ value was run in triplicate.

\subsection{Aggregation kinetics of $\mathrm{aqu} / \mathrm{nC}_{60}$ with and without HA}

Aggregation kinetics of the aqu/ $\mathrm{nC}_{60}$ in the presence and absence of HA were investigated under various ionic strengths using a time-resolved dynamic light scattering (DLS) technique. A portion of the stock aqu/ $/ \mathrm{nC}_{60}$ of $\mathrm{pH} 7.0$ with or without $10 \mathrm{mg} / \mathrm{L} \mathrm{HA}$ was added into a polystyrene measurement cell and the hydrodynamic sizes were recorded by the Zetasizer at an interval of $1 \mathrm{~min}$ for $30 \mathrm{~min}$ at $25^{\circ} \mathrm{C}$.
Various ionic strengths were obtained by mixing $0.5 \mathrm{ml}$ of $\mathrm{NaCl}, \mathrm{CaCl}_{2}$, or $\mathrm{LaCl}_{3}$ solutions of different concentrations into the cells containing aqu/ $\mathrm{nC}_{60}$ prior to the hydrodynamic size measurements. At the early stage of aggregation, the initial aggregation rate of the $\mathrm{aqu} / \mathrm{nC}_{60}$ can be expressed as

$$
\left(\frac{D_{\mathrm{h}}(t)}{\mathrm{d} t}\right)_{t \rightarrow 0} \propto k_{11} N_{0},
$$

where $D_{\mathrm{h}}(t)$ is the hydrodynamic size (nm) of $\mathrm{nC}_{60}$ at time $t, N_{0}$ is the initial particle concentration $(\mathrm{mg} / \mathrm{L})$, and $k_{11}$ is the initial aggregation rate constant (Chen and Elimelech, 2006; Chen et al., 2006). The initial rate of increase in $D_{\mathrm{h}}(t)$ is obtained by determining the initial slope up to the point where the hydrodynamic size reaches $1.25 D_{\mathrm{h}}(0)$.

The attachment efficiency $(\alpha)$ under different ionic strengths was calculated to quantify the aggregation kinetics of the aqu/ $\mathrm{nC}_{60}$ :

$$
\alpha=\frac{k_{11}}{\left(k_{11}\right)_{\text {fast }}}=\frac{\frac{1}{N_{0}}\left(\frac{\mathrm{d} D_{h}(t)}{\mathrm{d} t}\right)_{t \rightarrow 0}}{\frac{1}{\left(N_{0}\right)_{\text {fast }}}\left(\frac{\mathrm{d} D_{h}(t)}{\mathrm{d} t}\right)_{t \rightarrow 0, \text { fast }}},
$$

where $\left(k_{11}\right)_{\text {fast }}$ refers to $k_{11}$ in the diffusion controlled regime (Mashayekhi et al., 2012).

\section{Results and discussion}

\subsection{Characteristics of $\mathbf{a q u} / \mathrm{nC}_{60}$ and $\mathrm{HA}$}

Selected properties of the $\mathrm{C}_{60}$ powder and HA are listed in Table 1 . The aggregate size of aqu/ $\mathrm{nC}_{60}$ as determined using TEM was (34.8 \pm 5.9$) \mathrm{nm}$ (Fig. 1). The transparent yellow aqu/ $\mathrm{nC}_{60}$ remained stable for several months during and after the experiments. The concentration of the stock aqu/ $\mathrm{nC}_{60}$ was $8.0 \mathrm{mg} \mathrm{C} / \mathrm{L}$ with the zeta potential of $-40.8 \mathrm{mV}$, hydrodynamic size of $172 \mathrm{~nm}$, and $\mathrm{pH}$ value of 7.0. Fig. 1 shows the $\mathrm{UV}$-vis absorbance spectrum of the aqu/ $\mathrm{nC}_{60}$. The $\mathrm{aqu} / \mathrm{nC}_{60}$ had absorption peaks at 269 and $350 \mathrm{~nm}$ as well as a broad band between 410 and $550 \mathrm{~nm}$, which were identified to be characteristics of $\mathrm{nC}_{60}$ suspension as previously reported (Hyung and Kim, 2009; Hwang and Li, 2010; Navarro et al., 2013). 


\subsection{Effect of $\mathrm{HA}$ on aqueous stabilization of $\mathbf{C}_{60}$}

Fig. 2 shows the changes of zeta potential, hydro-dynamic size, and UV800 of the $\mathrm{C}_{60}$ powder sonicated in water against a concentration of HA. The zeta potentials of the $\mathrm{C}_{60}$ powder in the presence of 0 $40 \mathrm{mg} / \mathrm{L} \mathrm{HA}$ were all lower than $-50 \mathrm{mV}$, and the electronegativity initially increased with increasing the HA concentration and then leveled off at about $-65 \mathrm{mV}$ (Fig. 2a). The greater electronegativity of the $\mathrm{C}_{60}$ powder in the presence of HA indicated a greater electrostatic repulsion among the $\mathrm{C}_{60}$ particles, which was evidenced by the smaller hydrodynamic sizes in the HA solutions (Fig. 2a). The hydrodynamic size of the $\mathrm{C}_{60}$ powder was $(953 \pm 145) \mathrm{nm}$ in the absence of $\mathrm{HA}$, which however decreased to $(516 \pm 31) \mathrm{nm}$ in the presence of $40 \mathrm{mg} / \mathrm{L} \mathrm{HA}$, suggesting that HA could disperse the $\mathrm{C}_{60}$ powder to some degree in water.

The increased electrostatic repulsion between $\mathrm{C}_{60}$ aggregates accompanied by decreased hydrodynamic size with increasing HA concentrations led to the enhanced aqueous suspension of $\mathrm{C}_{60}$ in the HA solutions, which was confirmed by the increased UV800 of the $\mathrm{C}_{60}$ powder in the HA solutions. UV800 of the $\mathrm{C}_{60}$-HA suspension was positively correlated with the HA concentration after settling for $0-2 \mathrm{~d}$, which was in accordance with the changes of zeta potential and hydrodynamic size against the HA concentration (Fig. 2b). However, the UV800 of the $\mathrm{C}_{60}$-HA suspensions decreased with increasing settling time. After settling for $2 \mathrm{~d}$, all of the $\mathrm{C}_{60}-\mathrm{HA}$ suspensions became transparent, suggesting the severe agglomeration and precipitation of the $\mathrm{C}_{60}$ aggregates. The above result implies that after being discharged, the hydrophobic $\mathrm{C}_{60}$ powder could hardly be dispersed and stabilized in the water environment even in the presence of HA.

\subsection{Effect of $\mathrm{pH}$ on aqueous stability of $\mathrm{aqu} / \mathrm{nC}_{60}$ with and without $\mathrm{HA}$}

The stability of aqu $/ \mathrm{nC}_{60}$ in the absence and presence of HA was investigated under various $\mathrm{pH}$ values. Dramatic increases in electronegativity of the $\mathrm{aqu} / \mathrm{nC}_{60}$ with and without $\mathrm{HA}$ were observed as $\mathrm{pH}$ increased from 3 to 6 , while the increases leveled off over pH 6 (Fig. 3). This suggests that the neutralization reaction between $\mathrm{H}^{+}$and the acidic surfaces of $\mathrm{aqu} / \mathrm{nC}_{60}$ occurred at low $\mathrm{pH}$ (Yang et al., 2013), thereby reducing the electronegativity and electrostatic repulsion among the $\mathrm{nC}_{60}$ aggregates and consequently causing the aggregation and destabilization of the aqu/ $\mathrm{nC}_{60}$ in the absence of HA. The aqu/ $\mathrm{nC}_{60}$ had a lower zeta potential in the presence of $10 \mathrm{mg} / \mathrm{L}$ $\mathrm{HA}$, and the differences between the zeta potentials

Table 1 Selected properties of $\mathrm{C}_{60}$ and $\mathrm{HA}$

\begin{tabular}{|c|c|c|c|c|c|c|c|c|}
\hline \multirow{2}{*}{ Material } & \multicolumn{4}{|c|}{ Elemental content $(\%)$} & \multirow{2}{*}{$\begin{array}{l}\text { Ash } \\
(\%)\end{array}$} & \multicolumn{3}{|c|}{ Acidic site $(\mathrm{mmol} / \mathrm{g})$} \\
\hline & $\mathrm{C}$ & $\mathrm{H}$ & $\mathrm{N}$ & $\mathrm{O}$ & & Total & $-\mathrm{COOH}$ & Phenolic $-\mathrm{OH}$ \\
\hline $\mathrm{C}_{60}$ & 99.70 & 0.01 & & & & & & \\
\hline HA & 59.90 & 3.94 & 1.50 & 31.50 & 3.20 & 7.15 & 4.25 & 2.90 \\
\hline
\end{tabular}

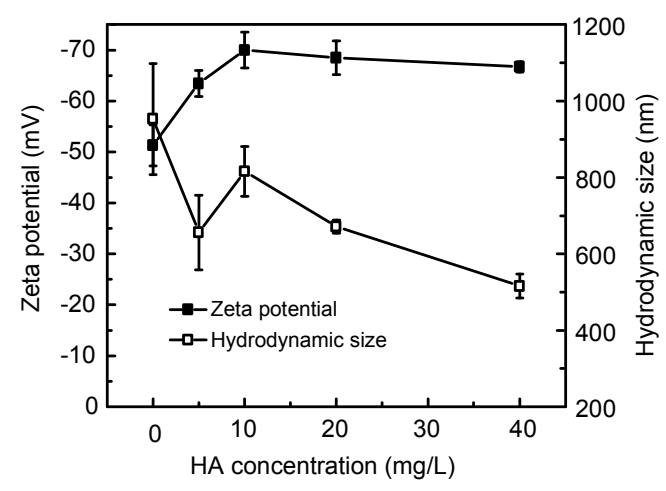

(a)

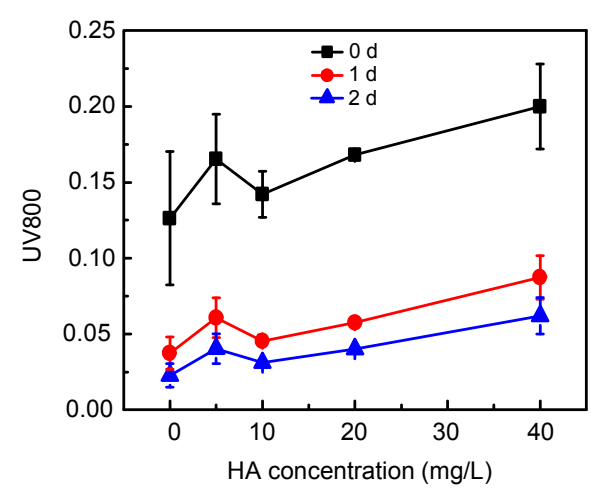

(b)

Fig. 2 Variations of zeta potential and hydrodynamic size (a) and UV-vis absorbance at $800 \mathrm{~nm}$ (UV800) (b) of $\mathrm{C}_{60}$ powder sonicated in water after settling for $0-2 \mathrm{~d}$ with $\mathrm{HA}$

Data are presented as mean \pm standard deviation, $n=3$ 
with and without HA became more significant under acidic conditions $(\mathrm{pH}<6)$. HA could be adsorbed by the $\mathrm{nC}_{60}$ aggregates (Mashayekhi et al., 2012), and the dissociation of $-\mathrm{COOH}$ and phenolic $-\mathrm{OH}$ groups of the surface-bound HA (Table 1) could impart negative charges on the $\mathrm{nC}_{60}$ aggregates, causing the difference in the zeta potential of the aqu/ $/ \mathrm{nC}_{60}$ with and without HA.

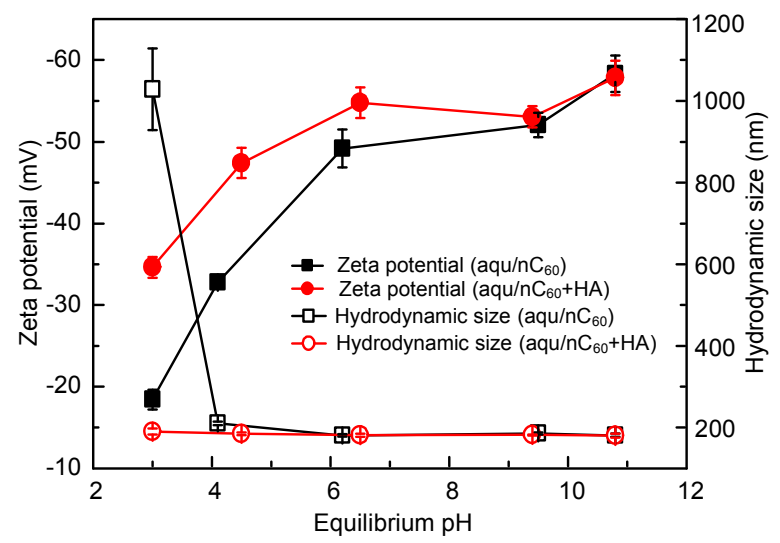

Fig. 3 Variations of zeta potentials and hydrodynamic sizes of the $\mathrm{aqu} / \mathrm{nC}_{60}$ with and without $\mathrm{HA}(10 \mathrm{mg} / \mathrm{L})$

The aqu $/ \mathrm{nC}_{60}$ retained its hydrodynamic size of (186 \pm 10$) \mathrm{nm}$ at $\mathrm{pH}>4$ with and without HA (Fig. 3). The hydrodynamic size of the $\mathrm{aqu} / \mathrm{nC}_{60}$ in the absence of HA sharply increased to $(1028 \pm 100) \mathrm{nm}$ at $\mathrm{pH}=3$, whereas it remained largely unchanged in the presence of HA (Fig. 3). The differences in the hydrodynamic size of the aqu $/ \mathrm{nC}_{60}$ with and without $\mathrm{HA}$ at $\mathrm{pH}=3$ could be explained by the differences in the zeta potential. At $\mathrm{pH}=3$, the zeta potential of the $\mathrm{aqu} / \mathrm{nC}_{60}$ increased to $(-18 \pm 1) \mathrm{mV}$ in the absence of $\mathrm{HA}$ while it remained lower than $-30 \mathrm{mV}$ in the presence of HA (Fig. 3). Colloids with absolute zeta potential $>30 \mathrm{mV}$ are considered to have strong electrostatic repulsions and tend to remain dispersed, while with the absolute zeta potential lower than $30 \mathrm{mV}$, they are prone to aggregation and destabilization due to the weak electrostatic repulsions among them (Lin et al., 2009; 2012a). The adsorbed HA could mitigate the neutralization reaction between $\mathrm{H}^{+}$ and the acidic surfaces of the $\mathrm{aqu} / \mathrm{nC}_{60}$, preventing the $\mathrm{nC}_{60}$ from aggregation, owing to the decreased electrostatic repulsion at low $\mathrm{pH}$ values. Moreover, the adsorbed HA could also enhance the aqueous stability of $\mathrm{aqu} / \mathrm{nC}_{60}$ via the increased steric hindrance among the $\mathrm{nC}_{60}$ aggregates. From the above results, we can see that the aqu/ $\mathrm{nC}_{60}$ would remain stabilized in the water environment with broad $\mathrm{pH}$ values, but would be subject to aggregation and destabilization at extremely low $\mathrm{pH}$ values; the coexisting HA is likely to help to stabilize the aqu/ $/ \mathrm{nC}_{60}$, especially at low $\mathrm{pH}$ values.

\subsection{Effect of ionic strength on aqueous stability of $\mathrm{aqu} / \mathrm{nC}_{60}$ with and without $\mathrm{HA}$}

3.4.1 Aggregation kinetics of the aqu $/ \mathrm{nC}_{60}$ in the absence of HA

Aggregation of the aqu/nC $\mathrm{n}_{60}$ occurred after the addition of various concentrations of the electrolytes as evidenced by the increase in its hydrodynamic size (Fig. 4). The cations at high concentrations immediately increased the aggregate size after their addition to the aqu/nC $\mathrm{nC}_{60}$. Fig. $4 \mathrm{a}$ shows the increasing of the aggregation rate of the aqu/ $\mathrm{nC}_{60}$ by increasing $\mathrm{Na}^{+}$ concentration from 50 to $400 \mathrm{mmol} / \mathrm{L}$ during $30 \mathrm{~min}$. The hydrodynamic size remained constant when $50 \mathrm{mmol} / \mathrm{L} \mathrm{Na}^{+}$was added. But the aggregation rate markedly increased with the concentration of $\mathrm{Na}^{+}$ increasing from 50 to $150 \mathrm{mmol} / \mathrm{L}$, and then remained steady with further addition of $\mathrm{Na}^{+}$. The attachment efficiencies $(\alpha)$ of the aqu $/ \mathrm{nC}_{60}$ at each $\mathrm{Na}^{+}$concentration were calculated according to Eq. (2) (Fig. 5a). The increase in $\mathrm{Na}^{+}$concentration could screen the surface charge of $\mathrm{nC}_{60}$, reduce the electrostatic energy barrier, and subsequently lead to the fast aggregation in the reaction controlled regime where $\alpha$ linearly increased with the increasing $\mathrm{Na}^{+}$concentration. However, once the electrolyte concentration was beyond the critical coagulation concentration (CCC), the energy barrier was completely eliminated and the diffusion controlled aggregation began. Under the diffusion controlled regime, $\alpha$ no longer responded to the increasing $\mathrm{Na}^{+}$concentration. Based on the data in Fig. 5a, the CCC, the intersection of the reaction and diffusion controlled regimes, was determined to be $142 \mathrm{mmol} / \mathrm{L}$ for $\mathrm{Na}^{+}$.

The DLS measurement was also applied to study the aggregation kinetics of $\mathrm{aqu} / \mathrm{nC}_{60}$ in the presence of $\mathrm{Ca}^{2+}$ and $\mathrm{La}^{3+}$. The increases in the hydrodynamic size with time were observed starting at 3 and $0.07 \mathrm{mmol} / \mathrm{L}$ of $\mathrm{Ca}^{2+}$ (Fig. 4c) and $\mathrm{La}^{2+}$ (Fig. 4e), respectively, revealing that much lower concentrations of the cations with higher valence were needed to destabilize the aqu $/ \mathrm{nC}_{60}$. This is because cations 
with higher valence have much higher capability of eliminating the energy barrier between the dispersed nanoparticles and thereby promoting the aggregation (Chen et al., 2006). The increase in aggregation rate of the aqu $/ \mathrm{nC}_{60}$ leveled off (i.e., $\alpha=1$ ) with the concentrations of $\mathrm{Ca}^{2+}$ and $\mathrm{La}^{3+}$ over 5 and $0.1 \mathrm{mmol} / \mathrm{L}$, respectively. Figs. $5 \mathrm{~b}$ and $5 \mathrm{c}$ show variations of $\alpha$ of the aqu/nC 60 with the concentrations of $\mathrm{Ca}^{2+}$ and $\mathrm{La}^{3+}$, where their CCCs were calculated to be 5.30 and $0.110 \mathrm{mmol} / \mathrm{L}$, respectively. The ratio of CCCs of the three electrolytes $\mathrm{NaCl}: \mathrm{CaCl}_{2}: \mathrm{AlCl}_{3}$ was 140:5.30: 0.110 (i.e., $1^{-4.78}: 2^{-4.78}: 3^{-4.78}$ ) (Fig. 5 d), which was
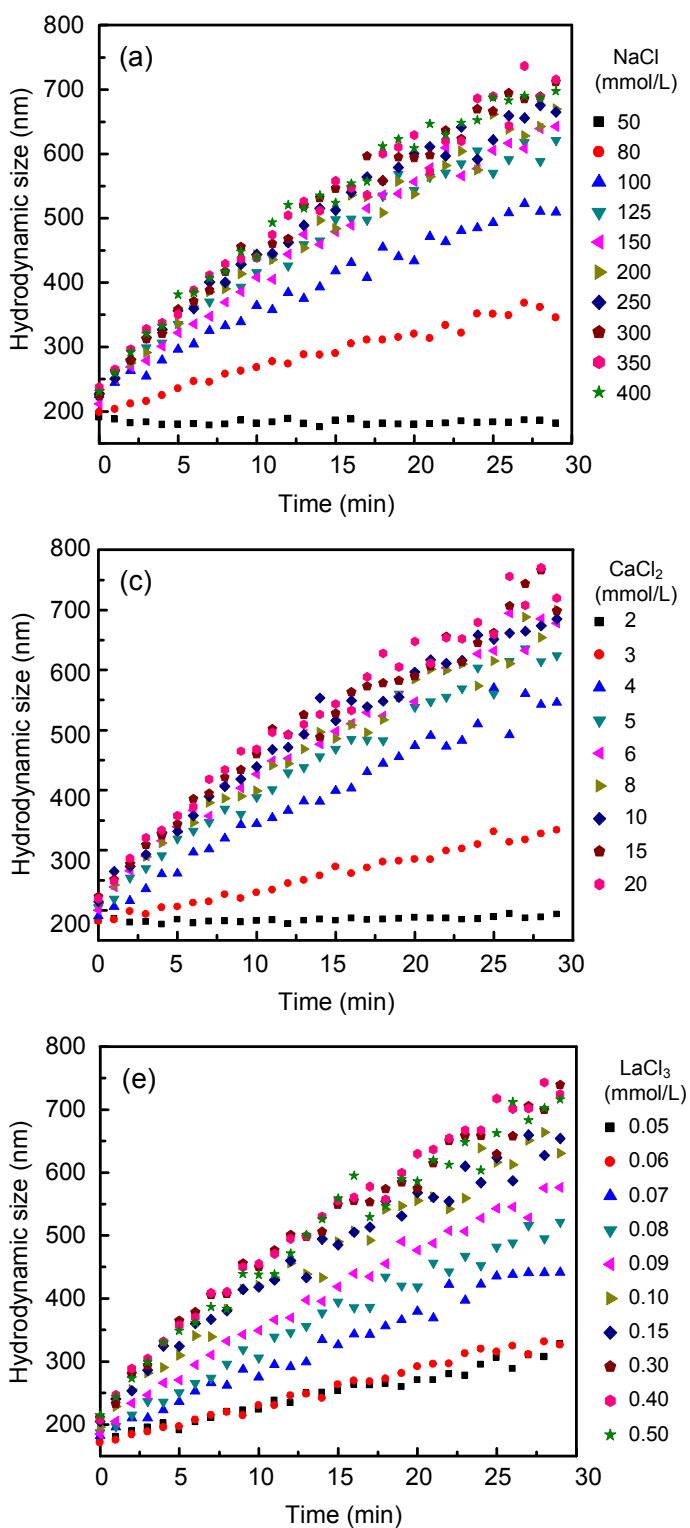

close to the ratio indicated by the Schulze-Hardy rule (i.e., $1^{-6}: 2^{-6}: 3^{-6}$ ) (Li and Huang, 2010).

Our $\mathrm{CCC}$ of $\mathrm{NaCl}$ is comparably higher than that determined by Chen and Elimelech (2006) for fullerene nanoparticles synthesized using the same technique $(120 \mathrm{mmol} / \mathrm{L})$. Their reported $\mathrm{CCC}$ of $\mathrm{CaCl}_{2}$ was $4.8 \mathrm{mmol} / \mathrm{L}$, which was close to our obtained result. It was noteworthy that the $\mathrm{CCC}$ values were quite similar, regardless of the 10 times higher suspension concentration which we employed, implying that the initial concentration of $\mathrm{aqu} / \mathrm{nC}_{60}$ may play an insignificant role in its aggregation.
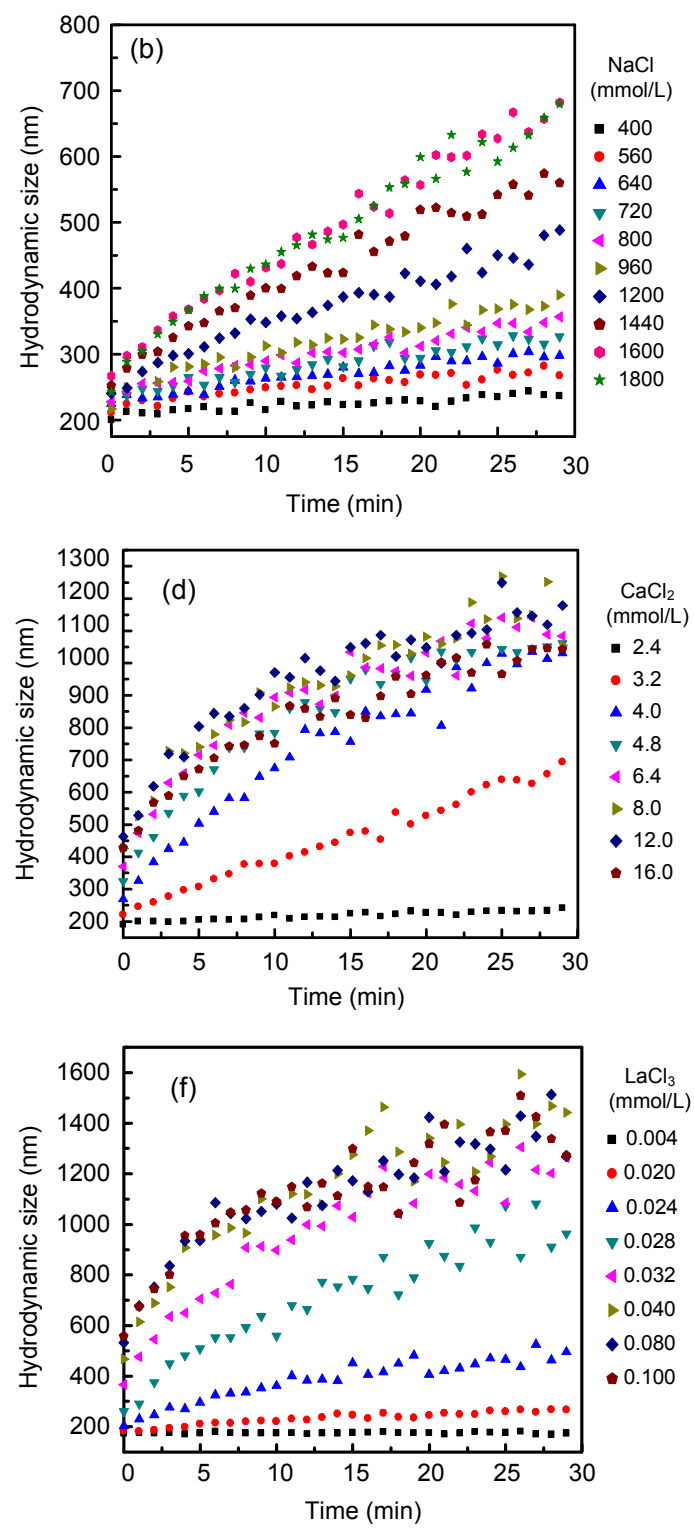

Fig. 4 Aggregation kinetics of the $\mathrm{aqu} / \mathrm{nC}_{60}$ at different concentrations of $\mathrm{NaCl}(\mathrm{a}, \mathrm{b}), \mathrm{CaCl}_{2}(\mathrm{c}, \mathrm{d})$, and $\mathrm{LaCl}_{3}(\mathrm{e}, \mathrm{f})$ in the absence (a, c, e) and presence $(b, d, f)$ of $10 \mathrm{mg} / \mathrm{L} \mathrm{HA}$ 

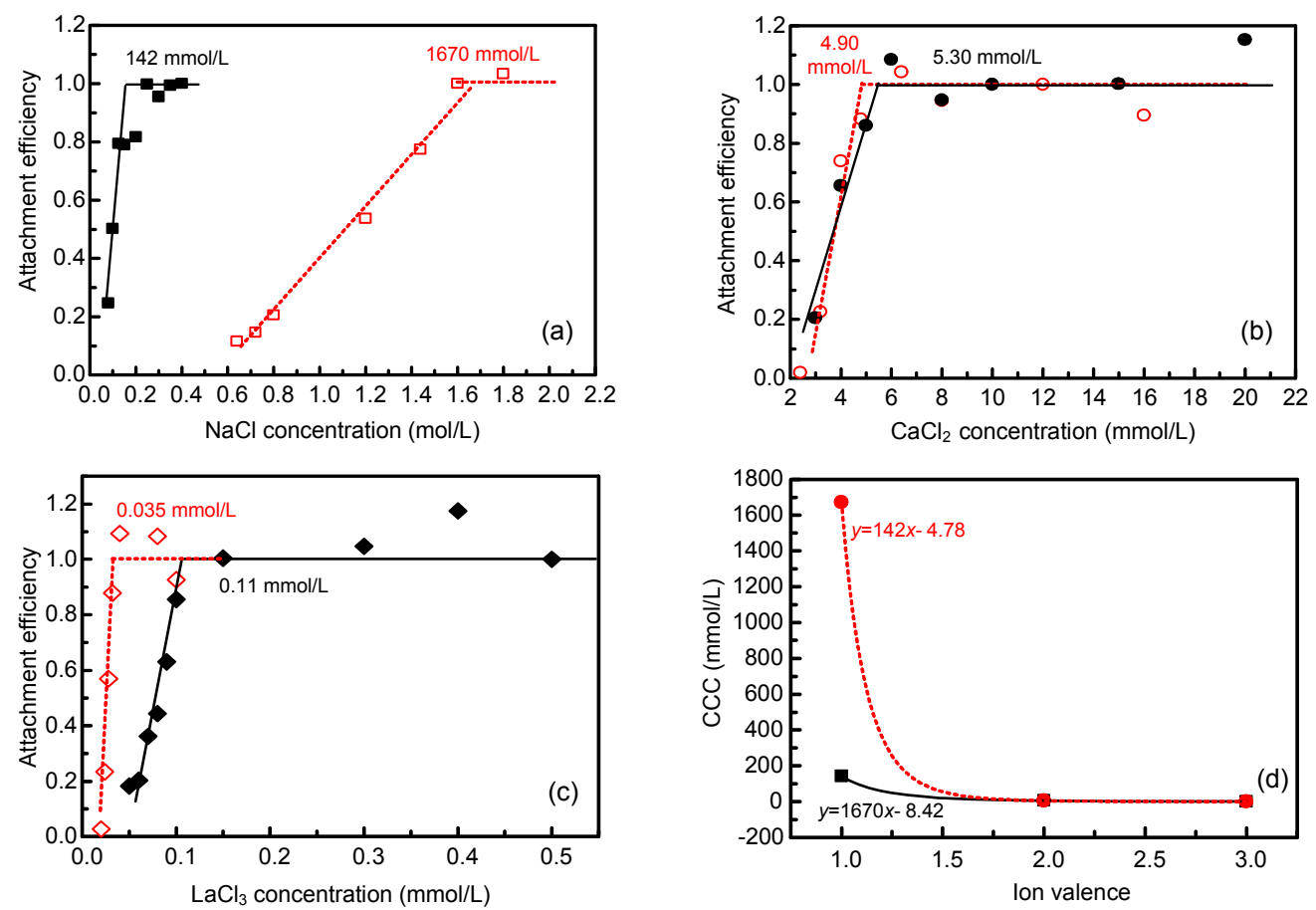

Fig. 5 Attachment efficiencies of the $\mathrm{aqu} / \mathrm{nC}_{60}$ at different concentrations of $\mathrm{NaCl}(\mathrm{a}), \mathrm{CaCl}_{2}(\mathrm{~b}), \mathrm{LaCl}_{3}$ (c), and the relationship between CCCs and cation valences (d) in the absence (solid lines) and presence (dash lines) of $10 \mathrm{mg} / \mathrm{L} \mathrm{HA}$

The CCCs of the eletrolytes were marked in the figures

\subsubsection{Aggregation of aqu/ $\mathrm{nC}_{60}$ in the presence of $\mathrm{HA}$}

The effects of HA on the aggregation rate of $\mathrm{aqu} / \mathrm{nC}_{60}$ at different concentrations of $\mathrm{NaCl}, \mathrm{CaCl}_{2}$, and $\mathrm{LaCl}_{3}$ are shown in Figs. 4b, 4d, and 4f, respectively. aqu/ $/ \mathrm{nC}_{60}$ started to aggregate with the hydrodynamic size increasing with time at $\mathrm{Na}^{+}$concentrations higher than $600 \mathrm{mmol} / \mathrm{L}$ and did not reach its maximum aggregation rate until $1670 \mathrm{mmol} / \mathrm{L}$ (CCC) of $\mathrm{NaCl}$ (Fig. 5a). Clearly, the presence of HA effectively prevented the aqu/ $\mathrm{nC}_{60}$ from homoaggregation and forming bigger aggregates as affected by $\mathrm{NaCl}$. This was in accordance with the result of a previous study that $\mathrm{NOM}$ increased the stability of $\mathrm{nC}_{60}$ suspension (Duncan et al., 2008). It was supposed that the adsorption of $\mathrm{NOM}$ including $\mathrm{HA}$ on the $\mathrm{nC}_{60}$ aggregates could increase electrosteric repulsions and thereby enhance stabilization of the $\mathrm{nC}_{60}$ suspension (Chen and Elimelech, 2007). Environmental concentrations of $\mathrm{Na}^{+}$are generally much lower than $1670 \mathrm{mmol} / \mathrm{L}$, therefore the $\mathrm{Na}^{+}$effect on the stability of aqu/ $/ \mathrm{nC}_{60}$ could be ignored in the presence of $10 \mathrm{mg} / \mathrm{L} \mathrm{HA}$.
The aggregation rate of aqu $/ \mathrm{nC}_{60}$ started to increase at 3.2 and $0.02 \mathrm{mmol} / \mathrm{L}$ of $\mathrm{Ca}^{2+}$ (Fig. $4 \mathrm{~d}$ ) and $\mathrm{La}^{3+}$ (Fig. 4f) and the increase leveled off at 4.80 and $0.032 \mathrm{mmol} / \mathrm{L}$ of $\mathrm{Ca}^{2+}$ (Fig. 5b) and $\mathrm{La}^{3+}$ (Fig. 5c), respectively. According to Figs. $5 \mathrm{~b}$ and $5 \mathrm{c}$, the calculated CCCs were 4.90 and $0.035 \mathrm{mmol} / \mathrm{L}$ of $\mathrm{Ca}^{2+}$ and $\mathrm{La}^{3+}$, respectively, which were surprisingly lower than their respective CCCs in the absence of HA. The negative effect of $\mathrm{HA}$ on the stability of aqu $/ \mathrm{nC}_{60}$ as affected by $\mathrm{Ca}^{2+}$ was also observed by Chen and Elimelech (2007). The accelerated aggregation in the presence $\mathrm{HA}$ was attributed to the bridging of $\mathrm{nC}_{60}$ by the HA aggregates formed through the intermolecular bridging of HA macromolecules via cation complexation at high concentrations of cations with high valences (Chen and Elimelech, 2007). The ratio of CCCs of the three electrolytes $\mathrm{NaCl}: \mathrm{CaCl}_{2}: \mathrm{AlCl}_{3}$ in the presence of HA was 1670:4.90:0.035 (i.e., $1^{-8.42}$ : $2^{-8.42}: 3^{-8.42}$ ) (Fig. 5d), which was also largely comparable to the precipitation by the Schulze-Hardy rule (i.e., $1^{-6}: 2^{-6}: 3^{-6}$ ) (Li and Huang, 2010) but was different from the ratio in the absence of HA. This differences were owing to the different effects of the HA 
on the colloidal stability of the aqu/ $\mathrm{nC}_{60}$ as affected by the three electrolytes as addressed above.

\section{Conclusions}

The effects of HA on the aqueous stabilization of $\mathrm{C}_{60}$ powder and on the colloidal stability of $\mathrm{aqu} / \mathrm{nC}_{60}$ as affected by variations of $\mathrm{pH}$ and ionic strength were studied. $\mathrm{C}_{60}$ powder could be dispersed to some degree but hardly be stably suspended in the presence of HA. Low $\mathrm{pH}$ and high ionic strength would affect the colloidal stability of $\mathrm{aqu} / \mathrm{nC}_{60}$. Big aggregates formed at $\mathrm{pH}<4$, owing to the screening of surface charges of the aqu/ $\mathrm{nC}_{60}$ at such low $\mathrm{pH}$. However, the colloidal stability of $\mathrm{aqu} / \mathrm{nC}_{60}$ in the presence of $\mathrm{HA}$ was insensitive to $\mathrm{pH} 3-11$. It was supposed that HA could be adsorbed onto the surfaces of $\mathrm{nC}_{60}$ and the surface-bound HA increased the surface electronegativity of the $\mathrm{nC}_{60}$, and thereby mitigated the aggregation through electrosteric repulsion at low $\mathrm{pH}$ values. Cation valence and concentration had a profound effect on the destabilization of the $\mathrm{aqu} / \mathrm{nC}_{60}$. The CCCs of $\mathrm{Na}^{+}, \mathrm{Ca}^{2+}$, and $\mathrm{La}^{3+}$ in the presence and absence of HA were exponentially decreased with the increase in cationic valence. The presence of HA could mitigate the impact of $\mathrm{Na}^{+}$on the colloidal stability of $\mathrm{aqu} / \mathrm{nC}_{60}$, but enhanced the destabilization effect of $\mathrm{Ca}^{2+}$ and $\mathrm{La}^{3+}$ on the aqu/C 60 .

\section{References}

Bhatt, I., Tripathi, B.N., 2011. Interaction of engineered nanoparticles with various components of the environment and possible strategies for their risk assessment. Chemosphere, 82(3):308. [doi:10.1016/j.chemosphere.2010.10.011]

Britto, R.S., Garcia, M.L., Rocha, A.M., et al., 2012. Effects of carbon nanomaterials fullerene $\mathrm{C}_{60}$ and fullerol $\mathrm{C}_{60}(\mathrm{OH})_{18-22}$ on gills of fish Cyprinus carpio (Cyprinidae) exposed to ultraviolet radiation. Aquatic Toxicology, 114-115:80-87. [doi:10.1016/j.aquatox.2012.02.018]

Chen, K.L., Elimelech, M., 2006. Aggregation and deposition kinetics of fullerene $\left(\mathrm{C}_{60}\right)$ nanoparticles. Langmuir, 22(26):10994-11001. [doi:10.1021/la062072v]

Chen, K.L., Elimelech, M., 2007. Influence of humic acid on the aggregation kinetics of fullerene $\left(\mathrm{C}_{60}\right)$ nanoparticles in monovalent and divalent electrolyte solutions. Journal of Colloid and Interface Science, 309(1):126-134. [doi:10. 1016/j.jcis.2007.01.074]

Chen, K.L., Mylon, S.E., Elimelech, M., 2006. Aggregation kinetics of alginate-coated hematite nanoparticles in monovalent and divalent electrolytes. Environmental Science \& Technology, 40(5):1516-1523. [doi:10.1021/ es0518068]

Colvin, V.L., 2003. The potential environmental impact of engineered nanomaterials. Nature Biotechnology, 21(10): 1166-1170. [doi:10.1038/nbt875]

Deguchi, S., Alargova, R.G., Tsujii, K., 2001. Stable dispersions of fullerenes, $\mathrm{C}_{60}$ and $\mathrm{C}_{70}$, in water. Preparation and characterization. Langmuir, 17(19):6013-6017. [doi:10. 1021/la010651o]

Duncan, L.K., Jinschek, J.R., Vikesland, P.J., 2008. C 60 colloid formation in aqueous systems: effects of preparation method on size, structure, and surface, charge. Environmental Science \& Technology, 42(1):173-178. [doi:10. 1021/es071248s]

Hwang, Y.S., Li, Q.L., 2010. Characterizing photochemical transformation of aqueous $\mathrm{nC}_{60}$ under environmentally relevant conditions. Environmental Science \& Technology, 44(8):3008-3013. [doi:10.1021/es903713j]

Hyung, H., Kim, J.H., 2009. Dispersion of $\mathrm{C}_{60}$ in natural water and removal by conventional drinking water treatment processes. Water Research, 43(9):2463-2470. [doi:10. 1016/j.watres.2009.03.011]

Isaacson, C.W., Bouchard, D.C., 2010. Effects of humic acid and sunlight on the generation and aggregation state of $\mathrm{aqu} / \mathrm{C}_{60}$ nanoparticles. Environmental Science \& Technology, 44(23):8971-8976. [doi:10.1021/es103029k]

Kim, K., Jang, M., Kim, J., et al., 2010. Effect of preparation methods on toxicity of fullerene water suspensions to Japanese medaka embryos. Science of The Total Environment, 408(22):5606-5612. [doi:10.1016/j.scitotenv. 2010.07.055]

Kim, K.T., Jang, M.H., Kim, J.Y., et al., 2012. Embryonic toxicity changes of organic nanomaterials in the presence of natural organic matter. Science of The Total Environment, 426:423-429. [doi:10.1016/j.scitotenv.2012.03.050]

Li, M.H., Huang, C.P., 2010. Stability of oxidized singlewalled carbon nanotubes in the presence of simple electrolytes and humic acid. Carbon, 48(15):4527-4534. [doi:10.1016/j.carbon.2010.08.032]

Li, Q.L., Xie, B., Wang, Y.S., et al., 2009. Kinetics of $\mathrm{C}_{60}$ fullerene dispersion in water enhanced by natural organic matter and sunlight. Environmental Science \& Technology, 43(10):3574-3579. [doi:10.1021/es803603x]

Lin, D.H., Liu, N., Yang, K., et al., 2009. The effect of ionic strength and $\mathrm{pH}$ on the stability of tannic acid-facilitated carbon nanotube suspensions. Carbon, 47(12):28752882. [doi:10.1016/j.carbon.2009.06.036]

Lin, D.H., Liu, N., Yang, K., et al., 2010. Different stabilities of multiwalled carbon nanotubes in fresh surface water samples. Environmental Pollution, 158(5):1270-1274. [doi:10.1016/j.envpol.2010.01.020]

Lin, D.H., Li, T.T., Yang, K., et al., 2012a. The relationship between humic acid (HA) adsorption on and stabilizing multiwalled carbon nanotubes (MWNTs) in water: effects of HA, MWNT and solution properties. Journal of Hazardous Materials, 241-242:404-410. [doi:10.1016/j. jhazmat.2012.09.060] 
Lin, D.H., Tian, X.L., Li, T.T., et al., 2012b. Surface-bound humic acid increased $\mathrm{Pb}^{2+}$ sorption on carbon nanotubes. Environmental Pollution, 167:138-147. [doi:10.1016/j. envpol.2012.03.044]

Mashayekhi, H., Ghosh, S., Du, P., et al., 2012. Effect of natural organic matter on aggregation behavior of $\mathrm{C}_{60}$ fullerene in water. Journal of Colloid and Interface Science, 374(1):111-117. [doi:10.1016/j.jcis.2012.01.061]

Nakamura, E., Isobe, H., 2003. Functionalized fullerenes in water. The first 10 years of their chemistry, biology, and nanoscience. Accounts of Chemical Research, 36(11): 807-815. [doi:10.1021/ar030027y]

Navarro, D.A., Kookana, R.S., Kirby, J.K., et al., 2013. Behaviour of fullerenes $\left(\mathrm{C}_{60}\right)$ in the terrestrial environment: potential release from biosolids-amended soils. Journal of Hazardous Materials, 262:496-503. [doi:10.1016/j. jhazmat.2013.08.021]

Nel, A., Xia, T., Madler, L., et al., 2006. Toxic potential of materials at the nanolevel. Science, 311(5761):622-627. [doi:10.1126/science.1114397]

Oberdörster, E., Zhu S.Q., Blickley, T.M., et al., 2006. Ecotoxicology of carbon-based engineered nanoparticles: effects of fullerene $\left(\mathrm{C}_{60}\right)$ on aquatic organisms. Carbon, 44(6):1112-1120. [doi:10.1016/j.carbon.2005.11.008]

Qu, X.L, Hwang, Y.S., Alvarez, P.J., et al., 2010. UV irradiation and humic acid mediate aggregation of aqueous fullerene $\left(\mathrm{nC}_{60}\right)$ nanoparticles. Environmental Science \& Technology, 44(20):7821-7826. [doi:10.1021/es101947f]
Takada, H., Kokubo, K., Matsubayashi, K., et al., 2006. Antioxidant activity of supramolecular water-soluble fullerene evaluated by $\beta$-carotene bleachingassay. Bioscience, Biotechnology, and Biochemistry, 70(12):30883093. [doi:10.1271/bbb.60491]

Tian, X.L., Zhou, S., He, X., et al., 2010. Metal impurities dominate the sorption of a commercially available carbon nanotube for $\mathrm{Pb}(\mathrm{II})$ from water. Environmental Science \& Technology, 44(21):8144-8149. [doi:10.1021/es102156u]

van Wezel, A.P., Moriniere, V., Emke, E., et al., 2011. Quantifying summed fullerene $\mathrm{nC}_{60}$ and related transformation products in water using LC LTQ Orbitrap MS and application to environmental samples. Environment International, 37(6):1063-1067. [doi:10.1016/j.envint.2011. 03.020]

Xie, B., Xu, Z.H., Guo, W.H., et al., 2008. Impact of natural organic matter on the physicochemical properties of aqueous $\mathrm{C}_{60}$ nanoparticles. Environmental Science \& Technology, 42(8):2853-2859. [doi:10.1021/es702231g]

Yang, Y.K., Nakada, N., Nakajima, R., et al., 2013. pH, ionic strength and dissolved organic matter alter aggregation of fullerene $\mathrm{C}_{60}$ nanoparticles suspensions in wastewater. Journal of Hazardous Materials, 244-245:582-587. [doi:10.1016/j.jhazmat.2012.10.056]

Zhang, W., Rattanaudompol, U., Li, H., et al., 2013. Effects of humic and fulvic acids on aggregation of aqu $/ \mathrm{nC}_{60}$ nanoparticles. Water Research, 47(5):1793-1802. [doi:10. 1016/j.watres.2012.12.037]

\section{中文概要:}

\section{本文题目：腐殖酸对富勒烯 $\mathbf{C}_{60}$ 的悬浮作用}

The role of humic acid in stabilizing fullerene $\left(\mathrm{C}_{60}\right)$ suspensions

研究目的: 腐殖酸 ( $\mathrm{HA}$ ) 对富勒烯 $\left(\mathrm{C}_{60}\right)$ 粉末的悬浮作用以及 $\mathrm{pH}$ 、离子强度对 $\mathrm{HA}-\mathrm{C}_{60}$ 悬浮性能的影响。

创新要点: 研究水质条件对 $\mathrm{C}_{60}$ 悬浮性能的影响。

研究方法: 测定 $\mathrm{C}_{60}$ 粉末在 $\mathrm{HA}$ 溶液中的 zeta 电位, 水力学粒径和悬浮浓度; $\mathrm{HA}$ 存在下, $\mathrm{C}_{60}$ 悬浮体系的 zeta 电位与水力学粒径随 $\mathrm{pH}$ 的变化及 $\mathrm{C}_{60}$ 悬浮体系团聚动力学随离子强度的变化。

重要结论: $\mathrm{HA}$ 对 $\mathrm{C}_{60}$ 粉末起到一定的分散作用, 但不能使其长时间稳定悬浮于水中。当 $\mathrm{pH}<4$ 时, $\mathrm{C}_{60}$ 水 悬液开始沉淀; 而当 $\mathrm{HA}$ 存在时, $\mathrm{C}_{60}$ 水悬液在 $\mathrm{pH}$ 3-11 范围内都保持稳定, 这是由于 $\mathrm{HA}$ 吸 附于 $\mathrm{C}_{60}$ 表面, 通过静电排斥和空间位阻作用, 促进 $\mathrm{C}_{60}$ 分散悬浮。 $\mathrm{C}_{60}$ 水悬液的稳定性随盐离 子价位和浓度升高而降低。 $\mathrm{HA}$ 会抑制 $\mathrm{Na}^{+}$对 $\mathrm{C}_{60}$ 水悬液的脱稳作用; 但高价离子 $\mathrm{Ca}^{2+}$ 和 $\mathrm{La}^{3+}$ 存在时, $\mathrm{HA}$ 与 $\mathrm{C}_{60}$ 之间会发生桥联从而促进 $\mathrm{C}_{60}$ 水悬液脱稳沉淀。

关键词组：富勒烯; 腐殖酸; 胶体稳定性; 天然有机质；纳米材料 